\title{
Rheological behaviour and microstructure of pea protein/ $\kappa$-carrageenan/starch gels with different setting conditions
}

\author{
M.C. Nunes ${ }^{\mathrm{a}}$, A. Raymundo ${ }^{\mathrm{b}}$, I. Sousa ${ }^{\mathrm{c}, *}$ \\ ${ }^{a}$ Centro de Investigação em Reologia e Tecnologia Alimentar, Instituto Piaget-ISEIT de Mirandela, Avenida 25 de Abril, 5370-202 Mirandela, Portugal \\ ${ }^{\mathrm{b}}$ Centro de Investigação em Engenharia Alimentar e Biotecnologia, Instituto Piaget_ISEIT de Almada, \\ Quinta da Arreinela de Cima, 2800-305 Almada, Portugal \\ ${ }^{\mathrm{c}}$ Secção de Ciência e Tecnologia dos Alimentos, Instituto Superior de Agronomia, Universidade Técnica de Lisboa, \\ Tapada da Ajuda, 1349-017 Lisboa, Portugal
}

Received 8 December 2004; accepted 23 March 2005

\begin{abstract}
The aim of this work was to study the rheological properties and microstructure of pea protein/ $\kappa$-carrageenan/starch gels as affected by different cooling conditions. Dynamic oscillatory measurements for mixed gels, cooled at different rates, were conducted in a stresscontrolled rheometer in order to clarify the kinetics of gel formation and characterise the structure of the matured gels. Texture parameters were determined from the texture profile analysis using a texturometer. Microstructure was observed using confocal laser scanning microscopy. In order to understand the role of each hydrocolloid on the gel network, rheology of single component gels were also studied. The results showed that gel setting conditions had a significant influence on the phase separation process of pea protein and $\kappa$-carrageenan, and hence on the final structure and textural properties of the mixed gel. Slower cooling promotes an extensive phase separation between pea protein and $\kappa$-carrageenan. Consequently, the size of pea protein aggregates was larger at the lowest cooling rate and decreased with increasing cooling rate. At faster cooling, an increase in elastic modulus and texture parameters of the gels were observed. Comparison of cooling and maturation profiles for the mixed system with those obtained for the individual components suggested that the gelation mechanism of $\kappa$-carrageenan should govern that of the multicomponent gel.
\end{abstract}

(C) 2005 Elsevier Ltd. All rights reserved.

Keywords: Pea protein; к-Carrageenan; Starch; Mixed gel; Rheology; Texture; Confocal laser scanning microscopy

\section{Introduction}

Due to recent animal diseases, nutritional dependent illness and strong demand for healthy food, consumer attitudes towards protein based foods of animal origin have changed. There is a greater pressure for the direct consumption of vegetable proteins in food products. The challenge is to replace the animal proteins and processed food with 'Novel Protein Foods'.

Pea proteins, which are rather new industrial proteins, show a well balanced profile of amino acids, especially a high content in lysine (Schneider \& Lacampagne, 2000). Besides nutritional characteristics, their good functional

\footnotetext{
* Corresponding author. Tel.: + 35121 3653543; fax: + 351213653200 .

E-mail address: isabelsousa@isa.utl.pt (I. Sousa).
}

0268-005X/\$ - see front matter (C) 2005 Elsevier Ltd. All rights reserved. doi:10.1016/j.foodhyd.2005.03.011 properties, such as gelling, emulsifying and foaming properties (Bacon, Noel, \& Lambert, 1990; Bora, Brekke, \& Powers, 1994; Dagorn-Scaviner, Gueguen, \& Lefebvre, 1987; Gueguen, 1991, 2000; Ipsen, 1997; Koyoro \& Powers, 1987; Sosulski \& McCurdy, 1987; Sumner, Nielsen, \& Youngs, 1981; Tomoskozi, Lásztity, Haraszi, \& Baticz, 2001), have led to a greater interest in this protein source as a promising food ingredient and an alternative to the soybean protein.

The present work is part of a research project designed to develop 'dairy desserts-like' products in which milk proteins are fully replaced by an industrial pea protein isolate.

Reformulation of real food systems to introduce new ingredients may change its structure and perceived texture, since the product is a result of the many interactions between the different components. In gelled milk desserts, $\kappa$-carrageenan, a sulphated anionic polysaccharide, is frequently used in combination with starch, because 
the gelation phenomenon involves a highly specific interaction between $\kappa$-carrageenan and $\kappa$-casein (Stanley, 1990). Recently, this was attributed to the incompatibility between $\kappa$-carrageenan and casein micelles leading to phase separation (Bourriot, Garnier, \& Doublier, 1999) and to the effect of $\kappa$-carrageenan that could trap caseins in pores of gel networks, as proposed by Schorsch, Jones, and Norton (2000).

In fact, the synergistic interactions between polysaccharides and proteins have a great importance in many food gels. Thermodynamic incompatibility of proteins and polysaccharides in mixed systems is a general phenomenon. For sulphated polysaccharides, this means that when the $\mathrm{pH}$ is shifted away from protein isoelectric point and/or at high ionic strength, there is a tendency for each polymer to exclude the other from its polymer domain, with the increase in effective concentration of both (Grinberg \& Tolstoguzov, 1997; Morris, 1990; Tolstoguzov, 1998).

A synergistic effect between pea protein and $\kappa$-carrageenan in mixed gels was already demonstrated by Ipsen (1995, 1997), using rheological measurements. In recent work, it was demonstrated that the gelation ability of a complex mixture of pea protein, $\kappa$-carrageenan and native maize starch can be an interesting alternative to commercial dairy desserts (Nunes, Batista, Raymundo, Alves, \& Sousa, 2003). Further work suggested that interaction between pea protein and $\kappa$-carrageenan results in phase separation, probably due to the depletion flocculation mechanism, since the formation of $\kappa$-carrageenan network and protein aggregates network were observed by means of confocal laser scanning microscopy. Starch reinforces the gel structure acting as a filler (Nunes, Raymundo, \& Sousa, 2004a,b). A similar behaviour between proteins and $\kappa$-carrageenan was found for gelation of dispersions of soybean isolate at concentrations lower than the critical gelation concentration, attributed to a synergistic process in which both polymers contribute to water absorption and network formation (Molina Ortiz, Puppo, \& Wagner, 2004). Mixtures of fish gelatin and $\kappa$-carrageenan resulted in phase separation when carrageenan adapted the ordered conformation and forms a gel network (Haug, Draget, \& Smidsrod, 2004). It was also reported that $\kappa$-carrageenan is incompatible with $\beta$-lactoglobulin (Roesch, Cox, Compton, Happek, \& Corredig, 2004). In a recent work (Verbeken, Olivier, \& Dewettinck, 2004), the effect of starch on $\kappa$-carrageenan gelation in milk desserts was studied. The exclusion effect of swollen starch granules, promoting the concentration of $\kappa$-carrageenan in the continuous water phase, was found to have an important influence on rheological properties.

It is useful to understand how the complex mixtures of globular vegetable protein and polysaccharides behave under food processing conditions. The phase separation of the mixed biopolymer systems, their final structure and textural properties are strongly dependent on processing temperature/time, cooling rates, protein and polysaccharide contents, $\mathrm{pH}$ and salt conditions. During gel formation, all these factors can affect the dynamic process of competition between phase separation and gel formation. The effect of thermal treatment and composition on the mechanical properties of the mixed gel with pea protein, $\kappa$-carrageenan and starch was already studied (Nunes et al., 2004a,b). The objective of the present work is to evaluate the effect of cooling conditions on the gel-forming kinetics, final mechanical properties and microstructure of this complex mixture.

Dynamic oscillatory measurements (temperature, time and frequency sweep tests) were conducted in a stresscontrolled rheometer. Texture properties of the final gels were obtained in a texturometer. The microstructure of the gels was observed using confocal laser scanning microscopy. Additionally, rheology of single component gels formed under similar conditions was characterised as a reference for the study of the mixed system.

\section{Materials and methods}

\subsection{Materials}

Pea protein isolate (Pisane ${ }^{\circledR}$, Cosucra, Belgium), $\kappa$-carrageenan (Satiagel $^{\mathrm{TM}}$ AMP45, Degussa, France) and native maize starch (Vitena A, Copan, Portugal) were kindly provided by the respective manufacturers. Sucrose was commercial grade. Pea protein isolate has the following characteristics (Pisane ${ }^{\circledR}$ technical information): protein content $90 \pm 2 \%(N \times 6.25)$, dry matter $\left(102{ }^{\circ} \mathrm{C}\right)$ $95 \pm 2 \%$, ash $5 \pm 1 \%$ (natrium $0.70 \%$, calcium $0.15 \%$, phosphorus $0.52 \%$, magnesium $0.20 \%$, potassium $0.40 \%$ ), carbohydrates maximum $4.5 \%$, fats (E.P. extract) maximum $0.5 \%$, isoelectric point 4.5 .

\subsection{Methods}

\subsubsection{Preparation of the mixtures}

A formulation developed in a previous work (Nunes et al., 2003) with $2.34 \%$ (w/w) of pea isolate (corresponding to $2.0 \%(\mathrm{w} / \mathrm{w})$ of protein), $0.15 \%(\mathrm{w} / \mathrm{w})$ of $\kappa$-carrageenan, $2.5 \%(\mathrm{w} / \mathrm{w})$ of starch and $15 \%(\mathrm{w} / \mathrm{w})$ of sucrose was used. Mixed biopolymer solutions (500 g) were made by dispersing the dry ingredients in demineralised water, under mechanical stirring $(300 \mathrm{rpm}, 1 \mathrm{~h})$ at room temperature. No adjustment was made to the natural $\mathrm{pH}$ of the system ( $\mathrm{pH}$ varied between 7.3 and 8.0) and no salt was added, implying that the ionic content in the solutions originates from the biopolymers. The suspensions were heated up to $95^{\circ} \mathrm{C}$ in a thermally controlled water bath and kept at this temperature for $5 \mathrm{~min}$. For rheological measurements, the samples were immediately loaded onto the rheometermeasuring system. For texture and CSLM analysis, samples were, immediately, poured into $6 \mathrm{~cm}$ diameter cylindrical containers filled up to $3.5 \mathrm{~cm}$ height, which were then 
placed in the rheometer water bath. Cooling conditions of the flasks samples were monitored by a thermocouple.

Single solutions of the individual biopolymers, $16 \%$ $(\mathrm{w} / \mathrm{w})$ pea protein isolate, $5 \%(\mathrm{w} / \mathrm{w})$ maize starch and $1 \%$ (w/w) $\kappa$-carrageenan, were prepared only with demineralised water and biopolymer and subjected to a similar thermal treatment.

\subsubsection{Rheological measurements}

Small-deformation measurements of storage moduli $\left(G^{\prime}\right)$ and loss moduli $\left(G^{\prime \prime}\right)$ were performed in a controlled-stress rheometer (RS-300, Haake, Germany), using cone-plate geometry $\left(35 \mathrm{~mm}, 2^{\circ}\right)$. Temperature was controlled by a Haake circulating water bath (DC30, Haake, Germany) and measured with a thermocouple attached to the stationary element. After thermal treatment, mixed systems were immediately transferred to the instrument plate, which was at 75,40 or $5^{\circ} \mathrm{C}$, covered with a layer of paraffin oil to prevent moisture loss and stabilised for a few minutes at this temperature. These starting temperatures define four different cooling profiles:

(A) cooling from $75{ }^{\circ} \mathrm{C}$ down to $5{ }^{\circ} \mathrm{C}$ at $0.1{ }^{\circ} \mathrm{C} / \mathrm{min}$ (in $11.7 \mathrm{~h}$ );

(B) cooling from $75{ }^{\circ} \mathrm{C}$ down to $5{ }^{\circ} \mathrm{C}$ at $0.5^{\circ} \mathrm{C} / \mathrm{min}$ (in $2.3 \mathrm{~h}$ );

(C) cooling from $40{ }^{\circ} \mathrm{C}$ down to $5{ }^{\circ} \mathrm{C}$ at $0.5^{\circ} \mathrm{C} / \mathrm{min}$ (in $1.2 \mathrm{~h}$ );

(D) quenching rapidly to $5{ }^{\circ} \mathrm{C}$ on the rheometer plate.

After cooling, time sweep tests were conducted at $5{ }^{\circ} \mathrm{C}$, during a reasonable period of time $(35 \mathrm{~h})$ at $1 \mathrm{~Hz}(6.28 \mathrm{rad} / \mathrm{s})$. After this period, without disturbing the gel, frequency sweeps were conducted at $5{ }^{\circ} \mathrm{C}$, with oscillation frequencies ranging from 0.01 to $115.6 \mathrm{rad} / \mathrm{s}$. A constant shear stress within the linear viscoelastic region of the material was used in all measurements. Each test was repeated at least three times and reproducible results were obtained.

Single biopolymer solutions after thermal treatment were, immediately, loaded on the rheometer plate and cooled from $40{ }^{\circ} \mathrm{C}$ down to $5{ }^{\circ} \mathrm{C}$ at $0.5^{\circ} \mathrm{C} / \mathrm{min}$ (cooling profile $\mathrm{C}$ ). After cooling, time sweep tests during $24 \mathrm{~h}$ were obtained at $5{ }^{\circ} \mathrm{C}$.

\subsubsection{Texture characterisation}

Texture parameters were determined from the texture profile analysis (TPA) using a TA-XT2i (Stable Micro Systems, UK) texturometer. Penetration tests were performed with a cylindrical probe $(25 \mathrm{~mm}$ diameter, $10 \mathrm{~mm}$ of penetration, $5 \mathrm{~s}$ of waiting time and $2 \mathrm{~mm} / \mathrm{s}$ of crosshead speed). The experiments were carried out 8 days after preparation, in order to allow full maturation of the mixed gels. Before performing any measurements, gels were allowed to equilibrate at $20^{\circ} \mathrm{C}$ for approximately $3 \mathrm{~h}$ in a temperature-controlled room. Results for each gel were determined at least three times. Firmness $(\mathrm{N})$ was considered as the maximum resistance to the penetration of the probe and was calculated as the height of the force peak during the first compression cycle. These gels break under puncture so a true peak is obtained before $10 \mathrm{~mm}$ distance. Adhesiveness represented the work necessary to pull the probe away from the sample and was recorded as the negative force area of the first compression (Bourne, 2002).

\subsubsection{Confocal scanning laser microscopy}

Confocal Laser Scanning Microscopy (CLSM) was performed with a Leica Microsystems (SP2, AOBS), using $20 \times / 0.7 \mathrm{NA} / \mathrm{dry} / \mathrm{HCPL}-\mathrm{APO}$ and $40 \times / \mathrm{UV} / 1.25$ NA/oil/HCXPL-APO CS objective lenses. The light source was an argon laser. Protein autofluorescence was analysed using $488 \mathrm{~nm}$ excitation and emission was recorded between 520 and $600 \mathrm{~nm}$. Fluorescent probe rhodamine B (Sigma, USA) was used for the non-covalent labelling of protein and starch. Rhodamine B was added during the mechanical stirring of the mixtures $(0.01 \mathrm{~g}$ rhodamine/500 g). In this case, the excitation wavelength was $568 \mathrm{~nm}$ and emission maxima was $625 \mathrm{~nm}$. A slice of gel was cut with care from the flask to minimize structural damage, placed between a concave slide and a coverslip and then sealed to prevent evaporation.

\subsubsection{Statistical analysis}

Statistical analysis, ANOVA/MANOVA, Post-Hoc Comparisons-Scheffé Test, was performed using the Software STATISTICA (Version 5.0, Statsoft, Inc., USA). The significance level was set at $95 \%$.

\section{Results and discussion}

\subsection{Rheological results}

During the cooling process (Fig. 1), viscoelastic parameters $G^{\prime}$ and $G^{\prime \prime}$ present similar values from 75 or $40{ }^{\circ} \mathrm{C}$ down to $20^{\circ} \mathrm{C}$. Further cooling shows both $G^{\prime}$ (elastic component) and $G^{\prime \prime}$ (viscous component) increasing, but $G^{\prime}$ increases faster than $G^{\prime \prime}$ and close to $20^{\circ} \mathrm{C}$ there is a cross over of $G^{\prime}$ and $G^{\prime \prime}$, corresponding to the gelling temperature (Fig. 1A and B). For the gel in Fig. 1C, cooled down from 40 to $5{ }^{\circ} \mathrm{C}$ (C cooling profile), it was not possible to detect the sol-gel transition since it occurred earlier at a temperature higher than $40{ }^{\circ} \mathrm{C}$. Nevertheless, a sudden steep increase of $G^{\prime}$ with cooling below $20^{\circ} \mathrm{C}$ is shown, revealing a gel structure reinforcement. For the gel quenched to $5^{\circ} \mathrm{C}$ (D cooling profile), no cooling curves were obtained since cooling was practically instantaneous.

The effect of cooling rate on the viscoelastic parameters of the protein-polysaccharide complex mixtures can also be seen in Fig. 1. Below $20^{\circ} \mathrm{C}, G^{\prime \prime}$ values are comparable for the three different cooling profiles, but the $G^{\prime}$ values for the gel cooled in case A are higher compared with those of the gels cooled in B and C conditions. When the system is maintained at low temperatures for a long time, at slower 

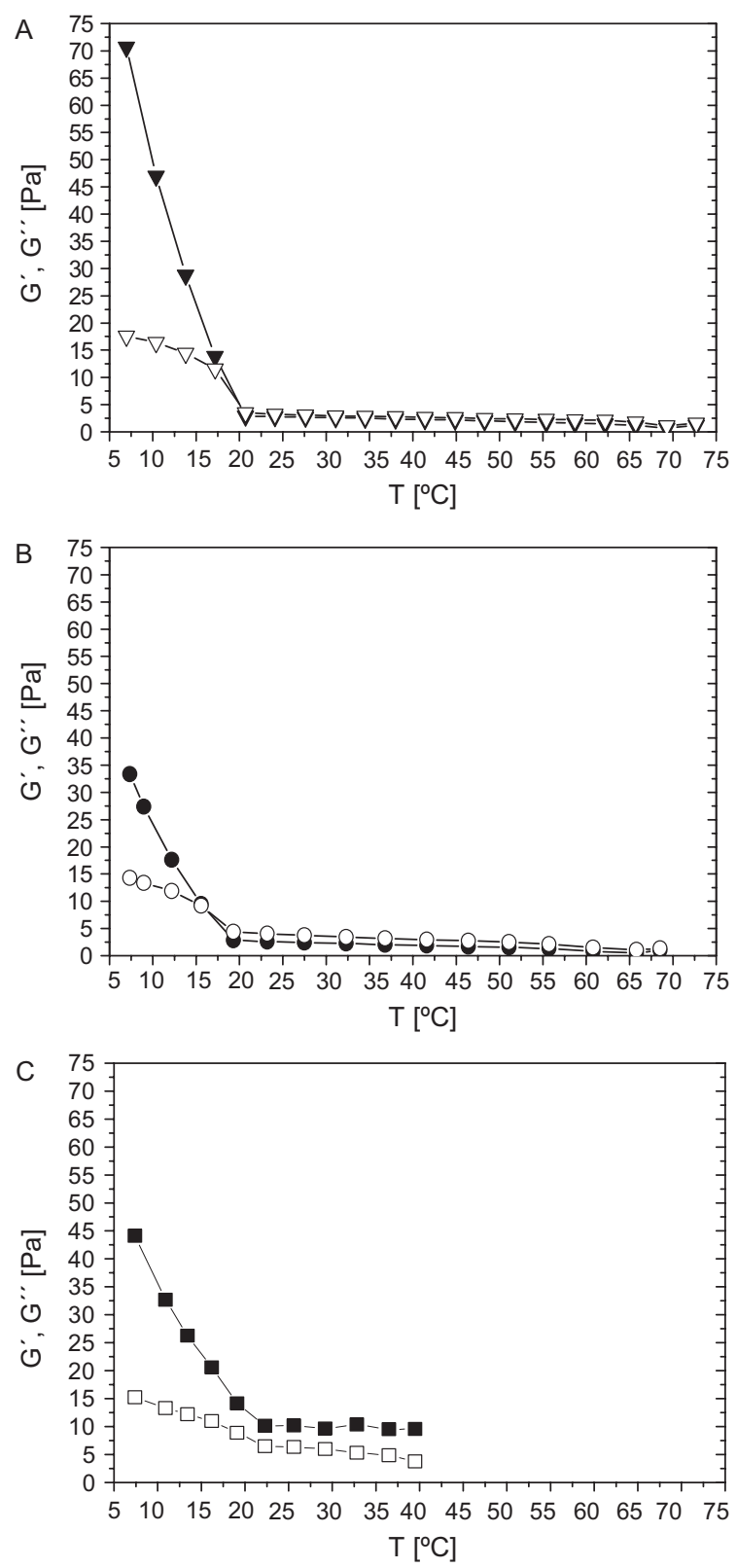

Fig. 1. Cooling curves of pea protein $/ \kappa$-carrageenan/starch mixtures, obtained at $6.28 \mathrm{rad} / \mathrm{s}$. A, ( $) 75$ to $5{ }^{\circ} \mathrm{C}$ at $0.1^{\circ} \mathrm{C} / \mathrm{min} ; \mathrm{B},(\bigcirc) 75$ to $5^{\circ} \mathrm{C}$ at $0.5^{\circ} \mathrm{C} / \mathrm{min} ; \mathrm{C},(\square) 40$ to $5^{\circ} \mathrm{C}$ at $0.5^{\circ} \mathrm{C} / \mathrm{min}$. $G^{\prime}$ (filled symbol), $G^{\prime \prime}$ (open symbol).

cooling rates, there is more time for dynamic equilibria of the gel network to take place, i.e. some gel structure maturation, leading to a more structured network on cooling.

In order to understand the role of each biopolymer on the gel network, cooling curves of single polymer gels were obtained from 40 down to $5{ }^{\circ} \mathrm{C}$ at $0.5{ }^{\circ} \mathrm{C} / \mathrm{min}$. According to Fig. 2, pea protein gel shows a progressive increase in $G^{\prime}$ during cooling, as reported for other globular proteins (Chronakis, Kasapis, Richardson, \& Doxastakis, 1995; Renkema \& Van Vliet, 2002). Thermal gelation of globular proteins involves the partial unfolding of protein molecular
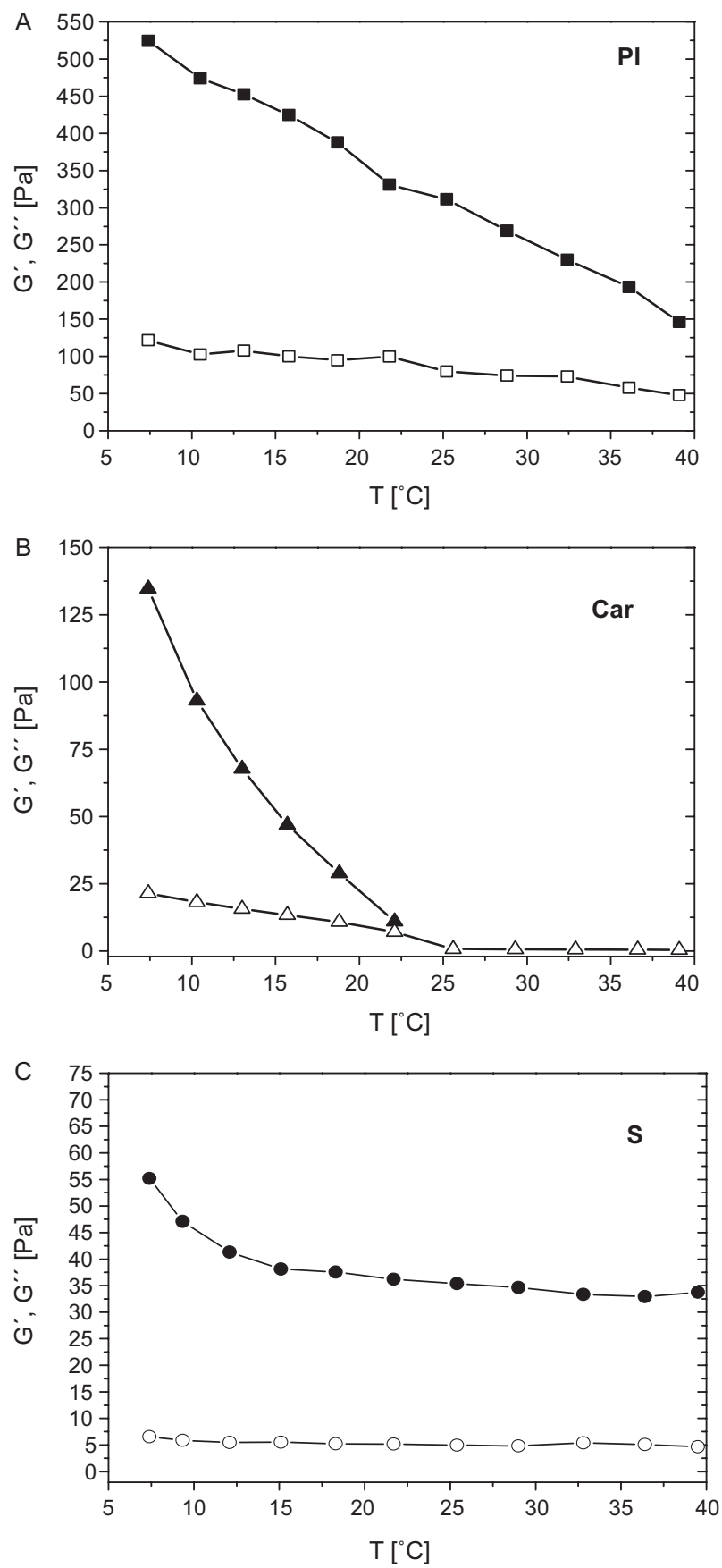

Fig. 2. Cooling curves from $40{ }^{\circ} \mathrm{C}$ down to $5{ }^{\circ} \mathrm{C}$ at $0.5^{\circ} \mathrm{C} / \mathrm{min}$ of single biopolymer gels, obtained at $6.28 \mathrm{rad} / \mathrm{s}$. PI, () $16 \% \mathrm{w} / \mathrm{w}$ pea protein isolate; Car, $(\boldsymbol{\Delta}) 1 \%$ w/w $\kappa$-carrageenan; $\mathrm{S},(\boldsymbol{\bigcirc}) 5 \%$ w/w maize starch. $G^{\prime}$ (filled symbol), $G^{\prime \prime}$ (open symbol).

strands at high temperatures, and subsequent aggregation and cross-linking to form a gel network, during cooling (Clark, Kavanagh, \& Ross-Murphy, 2001). The slight variation in $G^{\prime}$ during cooling of starch paste (Fig. 2C) must be the combined effect of the gradual change of the swollen granules and the formation of an amylose gel network (Miles, Morris, Orford, \& Ring, 1985). In the case of $\kappa$-carrageenan (Fig. 2B), there is an abrupt increase in $G^{\prime}$ 


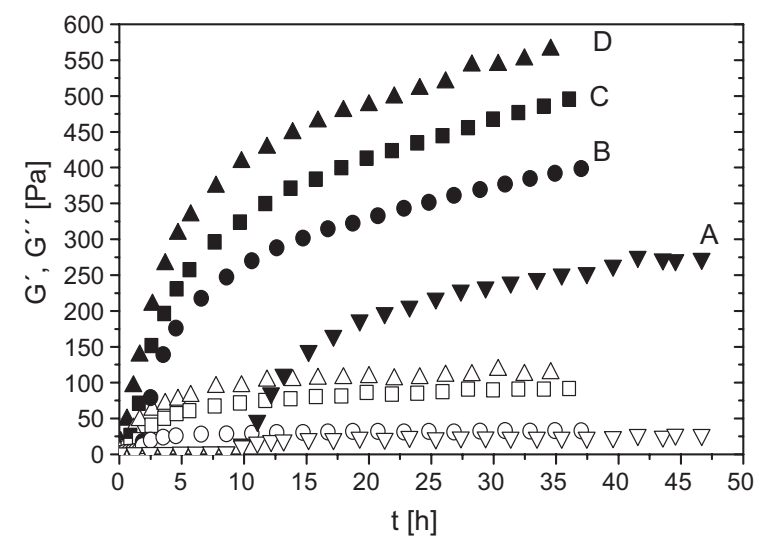

Fig. 3. Combined controlled cooling of pea protein/ $\kappa$-carrageenan/starch gels and isothermal run at $5{ }^{\circ} \mathrm{C}$ for $35 \mathrm{~h}$, obtained at $6.28 \mathrm{rad} / \mathrm{s}$. A, ( $\left.\nabla\right) 75$ to $5{ }^{\circ} \mathrm{C}$ at $0.1{ }^{\circ} \mathrm{C} / \mathrm{min} ; \mathrm{B},(\bigcirc) 75$ to $5{ }^{\circ} \mathrm{C}$ at $0.5^{\circ} \mathrm{C} / \mathrm{min} ; \mathrm{C}$, (ם) 40 to $5^{\circ} \mathrm{C}$ at $0.5^{\circ} \mathrm{C} / \mathrm{min}$; D, ( $\left.\boldsymbol{\Delta}\right)$ quench to $5^{\circ} \mathrm{C}$. $G^{\prime}$ (filled symbol), $G^{\prime \prime}$ (open symbol). Data were obtained every $30 \mathrm{~min}$. For clarity, only some of the experimental points are shown.

around $20^{\circ} \mathrm{C}$, corresponding to the gelling temperature (Chen, Liao, \& Dunstan, 2002), although $G^{\prime}$ was not detectable at higher temperatures. It is already known (Rochas \& Rinaudo, 1984; Yuguchi, Thi Thu Thuy, Urakawa, \& Kajiwara, 2002) that $\kappa$-carrageenan gelation is due to a two-step phenomenon involving the conformational transition from single chain to double helix followed by aggregation. Therefore, the sudden increase in $G^{\prime}$ around $20^{\circ} \mathrm{C}$ previously seen in the mixed system (Fig. 1), must be due to the $\kappa$-carrageenan gelation mechanism.

Combined controlled cooling of pea protein/ $\kappa$-carrageenan/starch gels and isothermal analysis at $5^{\circ} \mathrm{C}$ for $35 \mathrm{~h}$ are shown in Fig. 3. The maturation behaviour is typical of biopolymer gelation (Clark et al., 2001), with $G^{\prime}$ increasing rapidly at first and then more slowly. To calculate the $G^{\prime}$ at the pseudo-equilibrium state, when the gel reaches a stable and fully developed structure, we have previously used a simple mathematical expression (Nunes et al., 2003), since $G_{\text {eq }}^{\prime}$ is the value of $G^{\prime}$ at equilibrium when time is long enough,

$G_{\mathrm{eq}}^{\prime}=\lim _{t \rightarrow \infty} G^{\prime}(t)$

This can be written as:

$G_{\mathrm{eq}}^{\prime}=\lim _{(1 / t) \rightarrow 0} G^{\prime}(t)$ and results can be fitted to an exponential decay of the form

$G^{\prime}(k)=y_{0}+A_{1} \mathrm{e}^{-k / b_{1}}+A_{2} \mathrm{e}^{-k / b_{2}}$

where $y_{0}, A_{1}, A_{2}, b_{1}$ and $b_{2}$ are the equation parameters and $k$ is the reciprocal time i.e. $1 / t$. From Eq. (2), $G_{\text {eq }}^{\prime}$ can be extrapolated by fitting to experimental data. These parameters are summarised in Table 1. Accordingly, gels subjected to faster cooling rates showed higher $G_{\text {eq }}^{\prime}$ values, 335.1 Pa for the gel A compared with 774.2 Pa for the gel D. Nevertheless, gels at slower cooling will develop full structure sooner, as can be measured by the $\left(G_{\text {eq }}^{\prime}-G_{35 \mathrm{~h}}^{\prime}\right) / G_{\text {eq }}$ W ratio. This means that for the slowest cooling sample, an additional 0.19 of the $G_{\text {eq }}^{\prime}$ value was required to achieve full structure development compared to 0.27 of the $G_{\text {eq }}^{\prime}$ value for the fastest cooling sample.

The time course of gelation of single biopolymers during cooling and maturation (Fig. 4) show that $G^{\prime}$ of the $16 \%$ pea protein isolate gel increased faster in the first hours and reached a stable value after about $10 \mathrm{~h}$. This pattern of structural development diverges from the sigmoidal of the $1 \% \kappa$-carrageenan, which is similar to that found by Chen et al. (2002). It was clear that the shape of the $1 \%$ $\kappa$-carrageenan curve is more similar to that of the mixed system (Fig. 3), consistent with the greater impact of $\kappa$-carrageenan gelling mechanism on the mixed gelling system. $G^{\prime}$ of the starch gel first increased rapidly and then showed a slower increase in $G^{\prime}$, without reaching a steady value within the time of the experiment, in agreement with results reported by Ortega-Ojeda, Larsson, and Eliasson (2004) for mixtures of amylose and amylopectin. Thus, starch may be also contributing to the slow increase in $G^{\prime}$ during maturation of the mixed gel.

In conclusion, rheology of the single biopolymer gels suggested that the gelling mechanism of $\kappa$-carrageenan should govern that of the mixed system, i.e. the $\kappa$-carrageenan network becomes dominant over that of pea protein. This is an aspect that will be investigated in a future study using melting experiments. Rheological studies on mixtures of two of these hydrocolloids are also needed to confirm this result.

Frequency sweeps of the mixed gels at the end of the run at $5{ }^{\circ} \mathrm{C}$ are show in Fig. 5. All the gels presented a typical weak gel spectrum, i.e. $G^{\prime}$ is always higher than $G^{\prime \prime}$, at about one decade, and are both frequency dependent. The results show that cooling profile $\mathrm{D}$ gave a gel with a similar behaviour to that subjected to the $\mathrm{C}$ cooling profile. For gels

Table 1

Parameters of exponential decay (Eq. (3)) with the respective statistics and calculate $G_{\text {eq }}^{\prime}$ (Eq. (2)) for pea protein/א-carrageenan/starch gels at different cooling conditions

\begin{tabular}{|c|c|c|c|c|c|c|c|c|c|}
\hline & $y_{0}$ & $A_{1}$ & $b_{1}$ & $A_{2}$ & $b_{2}$ & $\chi^{2}$ & $G_{\mathrm{eq}}^{\prime}(\mathrm{Pa})$ & $G_{35 \mathrm{~h}}^{\prime}(\mathrm{Pa})$ & $G_{\mathrm{eq}}^{\prime}-G_{35 \mathrm{~h}}^{\prime} / G_{\mathrm{eq}}^{\prime}$ \\
\hline 75 to $5^{\circ} \mathrm{C}$ at $0.1^{\circ} \mathrm{C} / \mathrm{min}(\mathrm{A})$ & 102.2 & 138.5 & 0.224 & 94.4 & 0.044 & 19.98 & 335.1 & 273.1 & 0.19 \\
\hline 75 to $5^{\circ} \mathrm{C}$ at $0.5^{\circ} \mathrm{C} / \mathrm{min}(\mathrm{B})$ & 84.4 & 226.0 & 0.436 & 209.2 & 0.038 & 9.73 & 519.6 & 398.5 & 0.23 \\
\hline Quench to $5^{\circ} \mathrm{C}$ (D) & 49.5 & 466.0 & 0.36 & 258.6 & 0.025 & 19.70 & 774.2 & 564.3 & 0.27 \\
\hline
\end{tabular}




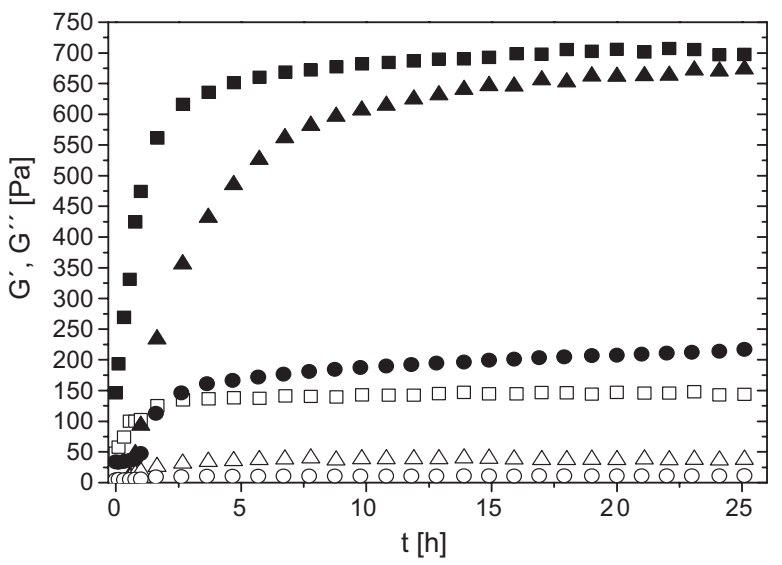

Fig. 4. Combined controlled cooling from $40{ }^{\circ} \mathrm{C}$ down to $5{ }^{\circ} \mathrm{C}$ at $0.5^{\circ} \mathrm{C} / \mathrm{min}$ of single biopolymer gels and isothermal run at $5{ }^{\circ} \mathrm{C}$ for $24 \mathrm{~h}$, obtained at

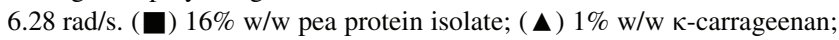
( ) $5 \%$ w/w maize starch. $G^{\prime}$ (filled symbol), $G^{\prime \prime}$ (open symbol). Data were obtained every $30 \mathrm{~min}$. For clarity, only some of the experimental points are shown.

at slow cooling (A and B), an increase on cooling rate seems to reinforce the gel structure. $G^{\prime}$ values of the gel B are similar to those of gels produced at rapid cooling (C and D), but the slopes of $G^{\prime}$ moduli are distinct. For gels at rapid cooling (C and D) $G^{\prime}$ is more frequency dependent at high frequencies.

\subsection{Texture results}

Macrostructure of the gels was evaluated in terms of texture, using the texture profile analysis (TPA). Meaningful texture parameters (firmness and adhesiveness) obtained for the mixed gels studied, are shown in Table 2. ANOVA/ MANOVA was used to compare results. The gel at slower cooling rate (A) showed the lowest firmness $(0.371 \mathrm{~N}$ compared with $0.502-0.627 \mathrm{~N}$ for the other gels). However, firmness of gels $\mathrm{C}$ and $\mathrm{D}$ are not significantly

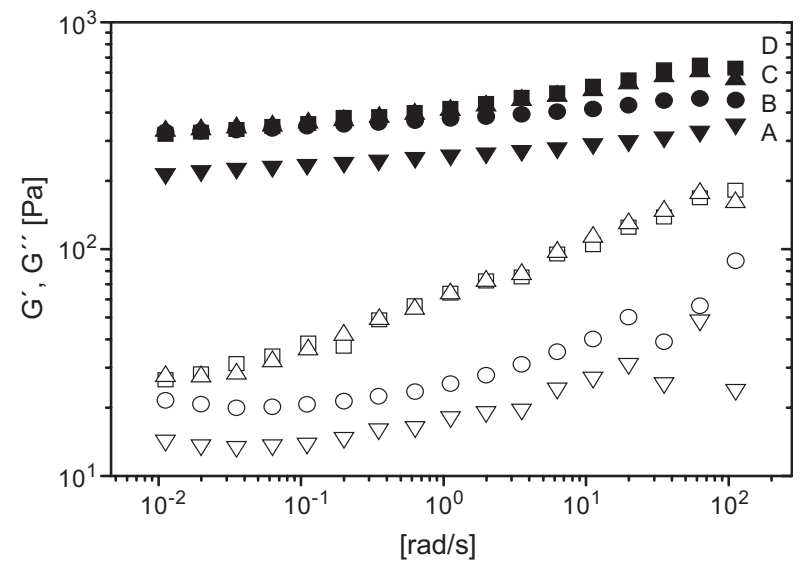

Fig. 5. Mechanical spectra of pea protein $/ \kappa$-carrageenan/starch gels at different cooling conditions, obtained at $5{ }^{\circ} \mathrm{C}$. A, ( $\left.\Delta\right) 75$ to $5{ }^{\circ} \mathrm{C}$ at $0.1^{\circ} \mathrm{C} / \mathrm{min}$; $\mathrm{B}$, ( ) 75 to $5^{\circ} \mathrm{C}$ at $0.5^{\circ} \mathrm{C} / \mathrm{min}$; $\mathrm{C}$, (口) 40 to $5^{\circ} \mathrm{C}$ at $0.5^{\circ} \mathrm{C} / \mathrm{min}$; D, ( $\left.\boldsymbol{\Delta}\right)$ quench to $5^{\circ} \mathrm{C}$. $G^{\prime}$ (filled symbol), $G^{\prime \prime}$ (open symbol).
Table 2

Values of texture parameters of pea protein/ $/$-carrageenan/starch gels at different cooling conditions

\begin{tabular}{lll}
\hline & Firmness (N) & Adhesiveness (N.s) \\
\hline 75 to $5^{\circ} \mathrm{C}$ at $0.1^{\circ} \mathrm{C} / \mathrm{min}(\mathrm{A})$ & 0.371 & 0.075 \\
75 to $5^{\circ} \mathrm{C}$ at $0.5^{\circ} \mathrm{C} / \mathrm{min}(\mathrm{B})$ & 0.502 & 0.115 \\
40 to $5^{\circ} \mathrm{C}$ at $0.5^{\circ} \mathrm{C} / \mathrm{min}(\mathrm{C})$ & $0.616^{*}$ & $0.165^{*}$ \\
Quench to $5^{\circ} \mathrm{C}$ (D) & $0.627^{*}$ & $0.147^{*}$ \\
\hline
\end{tabular}

*not significantly different $(p<0.05)$.

different $(p<0.05)$, in close agreement with rheology results. Similar results were found for adhesiveness.

Results obtained from small deformation rheology are in agreement with those found from large deformation test (TPA) of the same gels. Nevertheless, difference in volumes of analysed samples and in the heat transfer are obstacles to this direct comparison. The thermal profiles on cooling were compared using a thermocouple inside the flasks. Heat transfer is directly applied to the sample in the case of rheometer, but the flask cooled in the rheometer water bath from $40{ }^{\circ} \mathrm{C}$ down to $5{ }^{\circ} \mathrm{C}$ (profile $\mathrm{C}$ ) reaches the same temperature of the rheometer sample only after about $15 \mathrm{~min}$. It is worst in the case of the sample placed in the $5{ }^{\circ} \mathrm{C}$ waterbath (D conditions), in that only after about $15 \mathrm{~min}$ it reaches $10^{\circ} \mathrm{C}$ and $15 \mathrm{~min}$ later it is at $5^{\circ} \mathrm{C}$.

\subsection{CSLM}

Microscopic observations (Figs. 6 and 7) clearly show that phase separation between protein aggregates (white areas) and $\kappa$-carrageenan (grey areas) takes place.
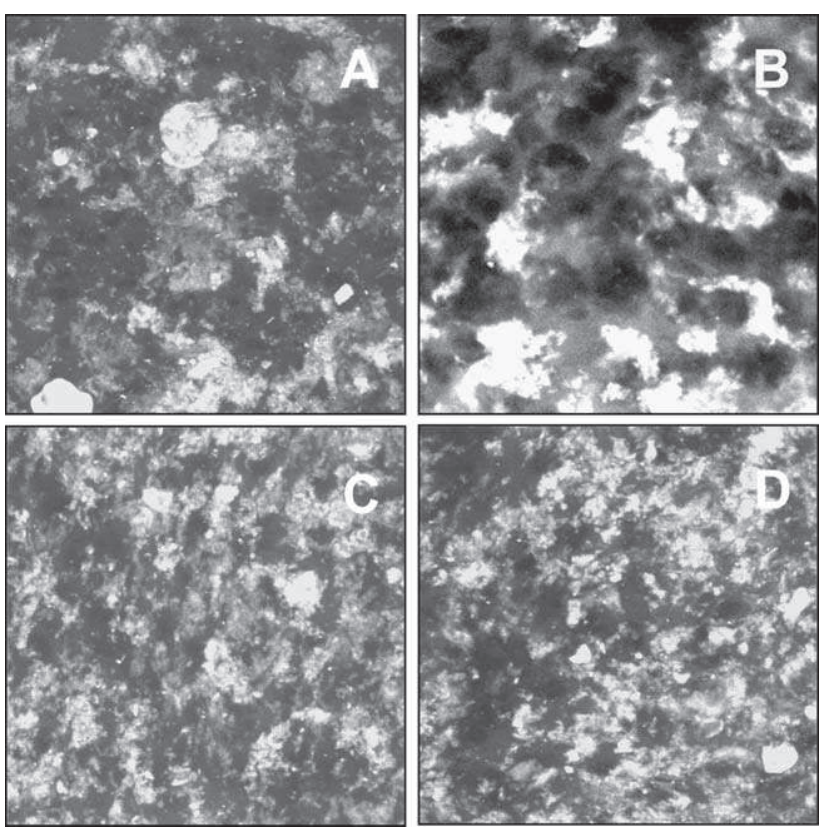

Fig. 6. CSLM images of pea protein/ $/$-carrageenan/starch gels at different cooling conditions, in autofluorescence mode. A, 75 to $5{ }^{\circ} \mathrm{C}$ at $0.1^{\circ} \mathrm{C} / \mathrm{min}$; $\mathrm{B}, 75$ to $5{ }^{\circ} \mathrm{C}$ at $0.5^{\circ} \mathrm{C} / \mathrm{min} ; \mathrm{C}, 40$ to $5^{\circ} \mathrm{C}$ at $0.5^{\circ} \mathrm{C} / \mathrm{min}$; $\mathrm{D}$, quench to $5^{\circ} \mathrm{C}$ (images size: $375 \times 375 \mu \mathrm{m}^{2}$ ). 


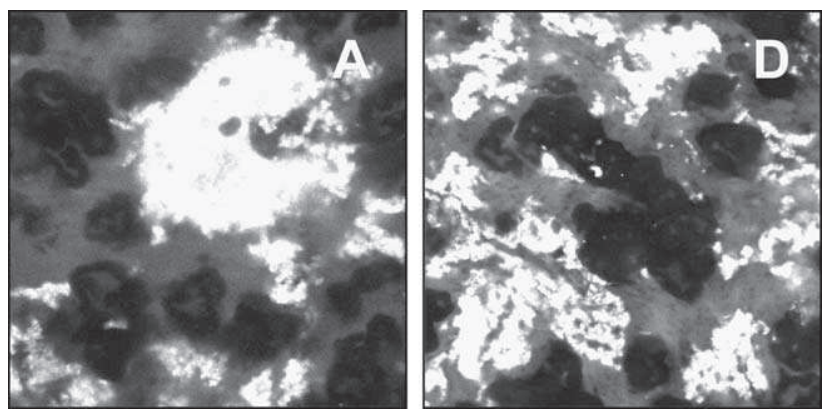

Fig. 7. CSLM images of pea protein/ $/$-carrageenan/starch gels at different cooling conditions, stained with rhodamine B. A, $75^{\circ}$ to $5^{\circ} \mathrm{C}$ at $0.1^{\circ} \mathrm{C} / \mathrm{min}$; $\mathrm{D}$, quench to $5^{\circ} \mathrm{C}$ (images size: $188 \times 188 \mu \mathrm{m}^{2}$ ).

This polysaccharide contributes to the thermodynamic activity of the protein solution, intensifying the aggregation of denatured protein molecules by depletion flocculation mechanism, and hence promoting the gelation process, as reported by Ipsen (1997). Therefore, the formation of a $\kappa$-carrageenan network and a network of protein aggregates are observed. Dark areas represent swollen starch granules, acting as a filler.

Gel setting conditions, i.e. cooling profiles, were determined as important to the phase separation process. The size of protein aggregates decreased with faster cooling, but $6 \mathrm{C}$ and $6 \mathrm{D}$ images are fairly similar, consistent with rheological and texture results. From image $6 \mathrm{~A}$ to $6 \mathrm{~B}$ there is a noticeable increase of the protein junction areas and in pictures $6 \mathrm{C}$ and $6 \mathrm{D}$ protein is evenly distributed in the gel matrix. This is also seen in the higher magnification images $7 \mathrm{~A}$ to $7 \mathrm{D}$ of the slowest and fastest cooling, respectively. These results give evidence that faster cooling rate slows down the phase separation process in favour of protein networking.

Rhodamine B, a protein selective probe, is also useful for the staining of starch granules. When high concentration of rhodamine $\mathrm{B}$ is used it is possible to clearly observe

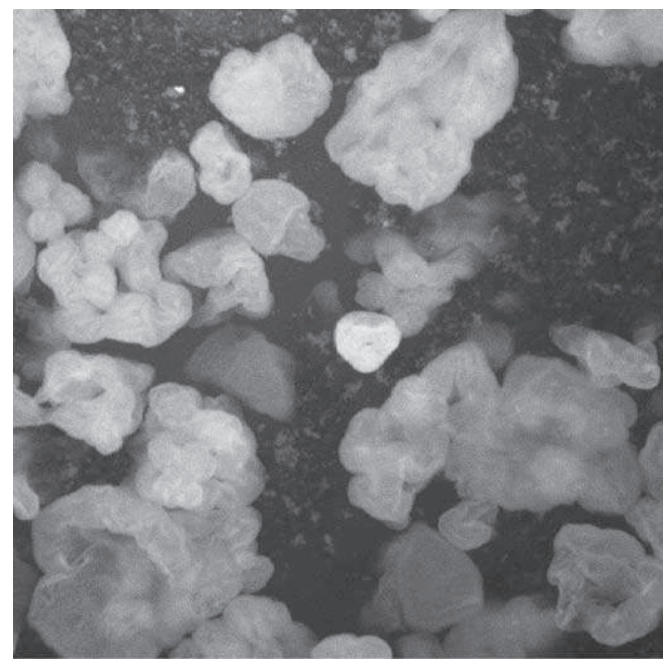

Fig. 8. CSLM image of a pea protein/ $\kappa$-carrageenan/starch gel cooled down to $5-7{ }^{\circ} \mathrm{C}$ in the refrigerator after the thermal treatment, stained with high concentration of rhodamine B $(0.2 \% \mathrm{w} / \mathrm{w})$ (image size: $\left.188 \times 188 \mu \mathrm{m}^{2}\right)$. the swollen starch granules and also the amylose leached out of the granule during gelatinisation process, in light grey (Fig. 8). The dark grey area corresponds to the protein phase, which is also coloured by rhodamine due to protein affinity (Van de Velde, Weinbreck, Edelman, Van der Linden, \& Tromp, 2003), but is not possible to distinguish protein and $\kappa$-carrageenan phases. Similar images of swollen starch granules were obtained by Van de Velde, Van Riel, and Tromp (2002) and Van de Velde et al. (2003) for custard desserts coloured with FITC.

\section{Conclusions}

Setting conditions were determined to influence the gelation process of pea protein/ $\kappa$-carrageenan/starch complex mixture. The thermal profile on cooling will affect gel structure and therefore rheology, texture and microstructure and probably will have an impact on the sensorial properties of the multicomponent gel. Microscopy experiments showed that cooling affects the phase separation process between pea protein and $\kappa$-carrageenan. Slower cooling rates allows for more complete phase separation with protein molecules structurally organized in larger aggregates. A rapid cooling enables an increase of the junction areas with evenly distribution of protein smaller aggregates. Thus, an increase in elastic modulus and texture parameters is obtained at rapid cooling. Rheology of single component gels suggested that the gelation mechanism of $\kappa$-carrageenan should govern that of the mixed gel.

\section{Acknowledgements}

This work is part of a research project, sponsored by FCT_Fundação para a Ciência e a Tecnologia (Reference POCTI/AGR/38251/2001) and C.I.E.R.T. of Instituto Piaget. Authors would like to acknowledge Dr José Feijó and Dr Nuno Moreno from Instituto Gulbenkian da Ciência (Portugal) for image analysis.

\section{References}

Bacon, J. R., Noel, T. R., \& Lambert, N. (1990). Preparation of transparent pea protein gels: A comparison of isolation procedures. International Journal of Food Science and Technology, 25, 527-537.

Bora, P. S., Brekke, C. J., \& Powers, J. R. (1994). Heat induced gelation of pea (Pisum sativum) mixed globulins, vicilin and legumin. Journal of Food Science, 59(3), 594-596.

Bourne, M. (2002). Food texture and viscosity: Concept and measurement. UK: Academic Press.

Bourriot, S., Garnier, C., \& Doublier, J. L. (1999). Micellar-casein-Кcarrageenan mixtures. I. Phase separation and ultrastructure. Carbohydrate Polymers, 40, 145-157.

Chen, Y., Liao, M. L., \& Dunstan, D. E. (2002). The rheology of $\mathrm{K}^{+}{ }^{-\kappa}-$ carrageenan as a weak gel. Carbohydrate Polymers, 50, 109-116. 
Chronakis, I. S., Kasapis, S., Richardson, R. K., \& Doxastakis, G. (1995). Characterisation of a commercial soy protein isolate by physical techniques. Journal of Texture Studies, 26, 371-389.

Clark, A. H., Kavanagh, G. M., \& Ross-Murphy, S. B. (2001). Globular protein gelation-theory and experiment. Food Hydrocolloids, 15, 383-400.

Dagorn-Scaviner, C., Gueguen, J., \& Lefebvre, J. (1987). Emulsifying properties of pea globulins as related to their adsorption behaviours. Journal of Food Science, 52(2), 335-341.

Grinberg, V. Ya, \& Tolstoguzov, V. B. (1997). Thermodynamic incompatibility of proteins and polysaccharides in solutions. Food Hydrocolloids, 11(2), 145-158.

Gueguen, J. (1991). Pea and fababean proteins. In B. J. F. Hudson (Ed.), Developments in food proteins-7 (pp. 35-78). Amsterdam: Elsevier Applied Science Publishers, 35-78.

Gueguen, J. (2000). Pea proteins: New and promising protein ingredients. Industrial Proteins, 8, 6-8.

Haug, I. J., Draget, K. I., \& Smidsrod, O. (2004). Physical behaviour of fish gelatin-К-carrageenan mixtures. Carbohydrate Polymers, 56, 11-19.

Ipsen, R. (1995). Mixed gels made from protein and $\kappa$-carrageenan. Carbohydrate Polymers, 28, 337-339.

Ipsen, R. (1997). Uniaxial compression of gels made from protein and K-carrageenan. Journal of Texture Studies, 28, 405-419.

Koyoro, H., \& Powers, J. R. (1987). Functional properties of pea globulin fractions. Cereal Chemistry, 64(2), 97-101.

Miles, M. J., Morris, V. J., Orford, P. D., \& Ring, S. G. (1985). The roles of amylose and amylopectin in the gelation and retrogradation of starch. Carbohydrates Research, 135, 271.

Molina Ortiz, S. E., Puppo, M. C., \& Wagner, J. R. (2004). Relationship between structural changes and functional properties of soy protein isolates-carrageenan systems. Food Hydrocolloids, 18, 1045-1053.

Morris, E. D. (1990). Mixed polymer gels. In P. Harris (Ed.), Food gels (pp. 291-359). London: Elsevier Applied Science, 291-359.

Nunes, M. C., Batista, P., Raymundo, A., Alves, M. M., \& Sousa, I. (2003). Vegetable proteins and milk puddings. Colloids and Surfaces B: Biointerfaces, 31, 21-29.

Nunes, M. C., Raymundo, A., \& Sousa, I. (2004a). Effect of thermal treatment and composition on the mechanical properties of pea/kappacarrageenan/starch desserts. In P. A. Williams, \& Glyn O. Phillips, Gums and stabilisers for the food industry (vol. 12) (pp. 54-64). UK: Royal Society of Chemistry, 54-64.

Nunes, M.C., Raymundo, A., \& Sousa, I. (2004b). Effect of composition on the rheological behaviour and microstructure of pea/kappa-carrageenan/starch gels. Book of proceedings of the IBEREO-04: Iberian Rheology Meeting (pp. 31-36).
Ortega-Ojeda, F. E., Larsson, H., \& Eliasson, A. C. (2004). Gel formation in mixtures of amylose and high amylopectin potato starch. Carbohydrate Polymers, 57, 55-66.

Renkema, J. M. S., \& Van Vliet, T. (2002). Heat-induced gel formation by soy proteins at neutral $\mathrm{pH}$. Journal of Agricultural and Food Chemistry, $50,1569-1573$.

Rochas, C., \& Rinaudo, M. (1984). Mechanism of gel formation in к-carrageenan. Biopolymers, 23, 735-745.

Roesch, R., Cox, S., Compton, S., Happek, U., \& Corredig, M. (2004). $\kappa$-Carrageenan and $\beta$-lactoglobulin interactions visualized by atomic force microscopy. Food Hydrocolloids, 18, 429-439.

Schneider, A., \& Lacampagne, J. P. (2000). Peas: A European production of protein-rich materials for feed and food. Industrial Proteins, 8, 3-6.

Schorsch, C., Jones, M. G., \& Norton, I. T. (2000). Phase behaviour of pure micellar casein/К-carrageenan systems in milk salt ultrafiltrate. Food Hydrocolloids, 14, 347-358.

Sosulski, F. W., \& McCurdy, A. R. (1987). Functionality of flours, protein fractions and isolates from field peas and faba bean. Journal of Food Science, 52(4), 1010-1014.

Stanley, N. F. (1990). Carrageenans. In P. Harris (Ed.), Food gels (pp. 79-119). London: Elsevier Applied Science, 79-119.

Sumner, A. K., Nielsen, M. A., \& Youngs, C. G. (1981). Production and evaluation of pea protein isolate. Journal of Food Science, 46(2), 364-366. See also page 372.

Tolstoguzov, V. B. (1998). Functional properties of protein-polysaccharide mixtures. In S. E. Hill, D. A. Ledward, \& J. R. Mitchell (Eds.), Functional properties of food macromolecules (pp. 252-275). Great Britain: Aspen Publishers, 252-275.

Tomoskozi, S., Lásztity, R., Haraszi, R., \& Baticz, O. (2001). Isolation and study of the functional properties of pea proteins. Nahrung-Food, 45(6), 399-401.

Van de Velde, F., Van Riel, J., \& Tromp, R. H. (2002). Visualisation of starch granule morphologies using confocal scanning laser microscopy (CSLM). Journal of the Science of Food and Agriculture, $82,1528-1536$

Van de Velde, F., Weinbreck, F., Edelman, M. W., Van der Linden, E., \& Tromp, R. H. (2003). Visualisation of biopolymer mixtures using confocal scanning laser microscopy (CSLM) and covalent labelling techniques. Colloids and Surfaces B: Biointerfaces, 31, 159-168.

Verbeken, D., Olivier, T., \& Dewettinck, K. (2004). Textural properties of gelled dairy desserts containing $\kappa$-carrageenan and starch. Food Hydrocolloids, 18, 817-823.

Yuguchi, Y., Thi Thu Thuy, T., Urakawa, H., \& Kajiwara, K. (2002). Structural characteristics of carrageenan gels: temperature and concentration dependence. Food Hydrocolloids, 16, 515-522. 